\title{
Microencapsulation Delivery System in Food Industry-Challenge and the Way Forward
}

\author{
Mingyi Yang, ${ }^{1}$ Ze Liang, ${ }^{1}$ Lei Wang, ${ }^{1}$ Ming Qi, ${ }^{1}$ Zisheng Luo, ${ }^{1,2,3}$ and Li Li $\mathbb{D}^{1,2,3}$ \\ ${ }^{1}$ Key Laboratory of Agro-Products Postharvest Handling, Ministry of Agriculture and Rural Affairs, College of Biosystems Engineering \\ and Food Science, Zhejiang University, Hangzhou 310058, China \\ ${ }^{2}$ Ningbo Research Institute, Zhejiang University, Ningbo 315100, China \\ ${ }^{3}$ National-Local Joint Engineering Laboratory of Intelligent Food Technology and Equipment, Zhejiang Key Laboratory for \\ Agro-Food Processing, Zhejiang Engineering Laboratory of Food Technology and Equipment, Zhejiang University, \\ Hangzhou 310058, China
}

Correspondence should be addressed to Li Li; lili1984@zju.edu.cn

Received 5 November 2019; Revised 18 June 2020; Accepted 23 June 2020; Published 13 July 2020

Academic Editor: Alexandra Muñoz-Bonilla

Copyright (c) 2020 Mingyi Yang et al. This is an open access article distributed under the Creative Commons Attribution License, which permits unrestricted use, distribution, and reproduction in any medium, provided the original work is properly cited.

\begin{abstract}
Microencapsulation is a promising technique, which provides core materials with protective barrier, good stability, controlled release, and targeting delivery. Compared with the pharmaceutical, cosmetic, and textile industries, food processing has higher requirements for safety and hygiene and calls for quality and nutrition maintenance. This paper reviews the widely used polymers as microcapsule wall materials and the application in different food products, including plant-derived food, animal-derived food, and additives. Also, common preparation technologies (emphasizing advantages and disadvantages), including spray-drying, emulsification, freeze-drying, coacervation, layer-by-layer, extrusion, supercritical, fluidized bed coating, electrospray, solvent evaporation, nanocapsule preparation, and their correlation with selected wall materials in recent 10 years are presented. Personalized design and cheap, efficient, and eco-friendly preparation of microcapsules are urgently required to meet the needs of different processing or storage environments. Moreover, this review may provide a reference for the microencapsulation research interests and development on future exploration.
\end{abstract}

\section{Introduction}

Microencapsulation is a physicochemical or mechanical process whereby one substance is embedded in another material, forming particles ranging from a few nanometers to a few millimeters. The global microencapsulation market was expected to expand at a compound annual growth rate of $13.70 \%$, rising to 19.35 billion dollars by 2025 [1]. Microcapsules have been widely used in the drug delivery market. Nowadays, microencapsulation is also highly recommended in food industry because of the benefits provided, such as thermostability enhancement, bioactive compound protection, controlled release, volatiles maintaining, odor shelter, and texture/sense improvement [2]. Figure 1 presents the life of microcapsules, from forming to fading. Core materials are microencapsulated in monolayer or multilayers of wall materials with a variety of molecular interactions, including electrostatic attraction, van der Waals forces, and hydrogen bonding or ionic interaction. The wall materials protect the core material from harsh temperature changes, oxygen, or moisture permeation during processing and storage. Finally, passing through human digestive system, the outer layers of microcapsules might be dissolved in gastric acid at lower $\mathrm{pH}$, then the core substances are released and absorbed in the small intestine. To adapt to different environmental conditions, the wall materials are designed to escort the core to target location.

The preparation of microcapsules requires simple equipment, continuous production, low production cost, and environmental friendliness. In addition, the most important thing for microcapsules applied in the food industry is to ensure that wall and core materials meet food safety 


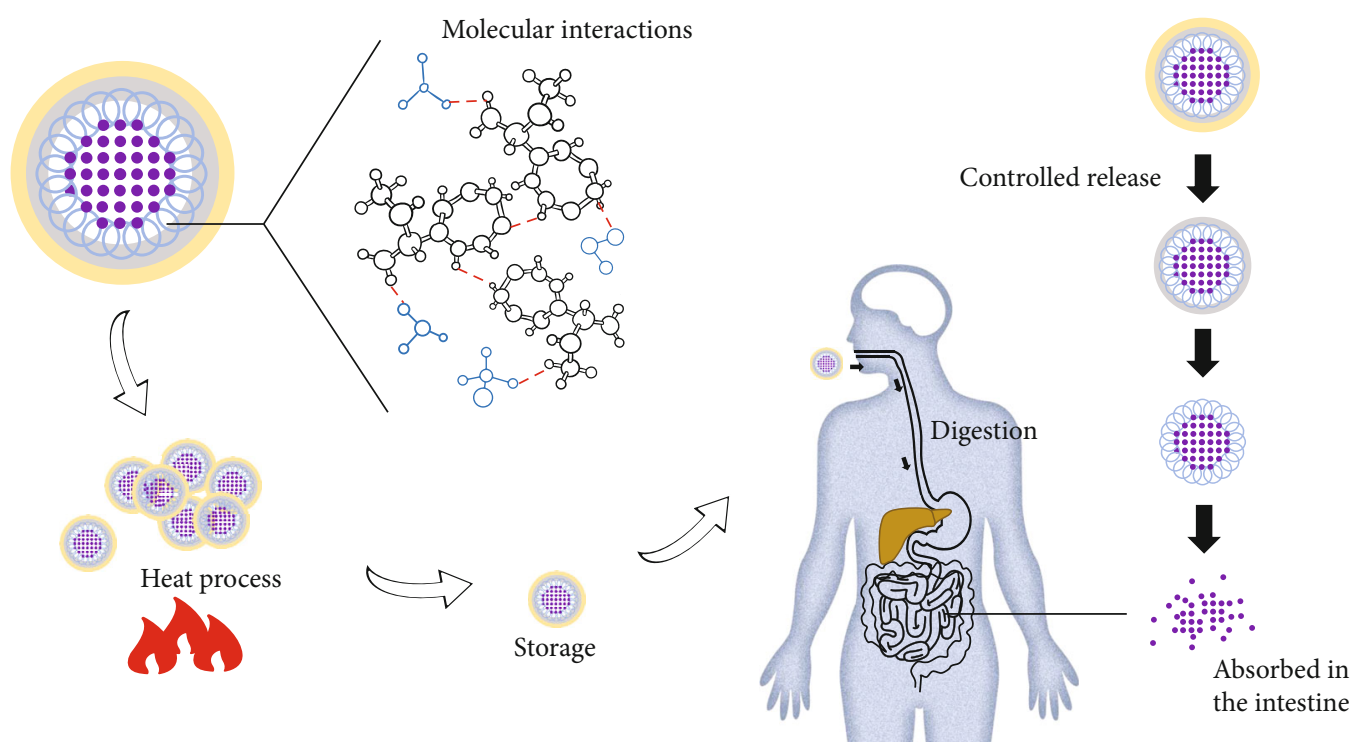

FIGURE 1: The life of microcapsule, forming to fading.

standards. Thus, strict requirements must be met including food grade raw and auxiliary materials and sanitary conditions of processing equipment. In the past few decades, the microencapsulation process has been constantly innovated to overcome the problems of easy degradation, low stability, and controlled release of functional components of food ingredients $[3,4]$. In particular, the modification of particle characteristics was achieved through different equipment, procedures, materials, processing conditions, and other technologies [3-5].

In this review, the polymers commonly used in wall materials such as polysaccharides and proteins and their different properties are discussed. Additionally, the latest update of microencapsulation applied in food industry, including plant-derived food, animal-derived food, and additives, is introduced. Moreover, the advantages and limitations of different embedding technologies, as well as the correlation between the selective biopolymer and microencapsulation process, are presented to offer new insight for further development.

\section{Polymers Used in Microencapsulation}

The profile of microcapsules with different wall materials and their characteristics is shown in Table 1.

2.1. Cellulose and Its Derivatives. Cellulose is a macromolecular substance composed of glucose and is one of the main components of plant cell wall, the most abundant polysaccharide and widely distributed in nature, accounting for more than $50 \%$ of the plant carbon content. In order to improve the solubility, the thermoplasticity, and other properties of products, the hydroxyl group in cellulose polymers is usually artificially esterified or etherified into derivatives, such as methyl cellulose (MC), carboxymethyl cellulose (CMC), hydroxypropyl cellulose (HPC), and hydroxypropyl methyl cellulose (HPMC) [34].
Probiotics Lactobacillus plantarum LAB12 was enclosed in alginate-cellulose derivatives, MC, CMC-Na, or HPMC. Results showed that alginate-MC and alginate-HPMC significantly reduced the vitality loss of LAB12 in comparison with alginate alone [10]. Besides, the microencapsulated LAB12 in alginate-MC and alginate-HPMC exhibited the higher survival rate of $91 \%$ under simulated gastric environment, with the maximal release of approximately $100 \%$ [10]. With the increase of MC and HPMC concentration, their viscosity increased, the stability and strength of the cementing network also increased, and the matrix and gel system became more compact, reducing the free volume of the matrix, thus blocked the release of probiotics during gastric transport [10]. Furthermore, intermolecular interactions in the gel network strengthened the bonding, while at low $\mathrm{pH}$, the gel network was weakened (molecular interactions were broken), leading to the release of probiotics [10]. Moreover, in order to increase the thermostability of probiotics Bifidobacterium animalis spp. lactis for powdered infant formula (PIF), the double-layered microcapsule with HPMC as an inner layer and HPC as the outer layer was performed to protect it against the high-temperature stress stimuli; and the presence of HPC with higher molecular weight and the thicker coating delayed the bacterial development after exposure to $70^{\circ} \mathrm{C}$ [35].

Oils, especially those rich in polyunsaturated fatty acids, tend to be oxidized and produce unpleasant odors; thus, oils are often essential to be sheltered in microcapsules. Cellulose derivative microcapsule enhanced the oil stability, and the variance in particle size and the shape affected the mobility, solubility, agglomeration, etc. [11, 13, 14] For instance, Karim et al. [13] optimized the encapsulation conditions of temperature $\left(60^{\circ} \mathrm{C}\right)$, pressure $(150 \mathrm{bar})$, and feed emulsion rate $\left(1.36 \mathrm{~mL} \mathrm{~min}^{-1}\right)$ of the microencapsulated fish oil. Results demonstrated that the higher concentration of HPMC contributed to the increase of particle density, wettability, and powder porosity [13]. In addition to coating effect, 
TABLE 1: Overview of microcapsules with various characteristics and bioactive effects.

\begin{tabular}{|c|c|c|c|c|c|}
\hline Wall material & Core material & $\begin{array}{l}\text { Embedding } \\
\text { technology }\end{array}$ & Characteristics & Bioactive effect & Ref. \\
\hline \multicolumn{6}{|l|}{ Algal extract } \\
\hline $\begin{array}{l}\text { Chitosan, alginate, chitosan/alginate, } \\
\text { chitosan/inulin }\end{array}$ & Coriander essential oil & Spray-drying & $\begin{array}{c}\text { Swelling degree } \uparrow, \\
\text { Release rate } \uparrow, \\
\text { Resistant to } \mathrm{pH} \text { and } \\
\text { temperature variations } \uparrow, \\
\text { Encapsulation efficiency } \uparrow\end{array}$ & & [6] \\
\hline Sodium alginate and calcium chloride & Wine waste & $\begin{array}{l}\text { Vibration } \\
\text { nozzle }\end{array}$ & Polyphenol stability $\uparrow$ & & [7] \\
\hline $\begin{array}{l}\text { Sodium alginate/sodium alginate-citric } \\
\text { pectin }\end{array}$ & Lactobacillus plantarum & Electrospray & $\begin{array}{l}\text { Cell viability } \uparrow, \\
\text { L. plantarum BL011 } \\
\text { survival } \uparrow\end{array}$ & & [8] \\
\hline Sugarcane bagasse and sodium alginate & $\begin{array}{l}\text { Lactobacillus } \\
\text { rhamnosus NRRL } 442\end{array}$ & Extrusion & $\begin{array}{l}\text { Thermotolerance } \uparrow \text {, } \\
\text { Cell survivability } \uparrow\end{array}$ & & [9] \\
\hline \multicolumn{6}{|l|}{ Cellulose } \\
\hline $\begin{array}{l}\text { Alginate with supplementation of } \\
\text { cellulose derivatives (methylcellulose, } \\
\text { sodium carboxymethyl cellulose or } \\
\text { hydroxypropyl methylcellulose }\end{array}$ & $\begin{array}{l}\text { Lactobacillus plantarum } \\
\text { LAB12 }\end{array}$ & Freeze-drying & The survival of LAB12 $\uparrow$ & $\begin{array}{l}\text { Protective delivery } \\
\text { for probiotic } \\
\text { strains }\end{array}$ & {$[10]$} \\
\hline Carboxymethyl cellulose or pullulan & $\begin{array}{l}\text { Tuna oil, tuna } \\
\text { oil/peppermint oil }\end{array}$ & Spray-drying & $\begin{array}{l}\text { Spherical microcapsules } \\
\text { with a smooth surface, } \\
\text { Oxidative stability } \uparrow\end{array}$ & $\begin{array}{l}\text { Higher antioxidant } \\
\text { capacity }\end{array}$ & {$[11]$} \\
\hline $\begin{array}{l}\text { Carboxymethyl cellulose sodium and } \\
\text { microcrystalline cellulose }\end{array}$ & Astaxanthin & Spray-drying & $\begin{array}{l}\text { Astaxanthin retention } \\
\text { value } \uparrow \\
\text { Attractive color }\end{array}$ & $\begin{array}{l}\text { Improved DPPH- } \\
\text { scavenging activity }\end{array}$ & {$[12]$} \\
\hline Hydroxypropyl methyl cellulose & Fish oil & $\begin{array}{l}\text { Supercritical } \\
\text { fluid } \\
\text { collection }\end{array}$ & $\begin{array}{c}\text { Particle flowability } \uparrow \text {, } \\
\text { Particle density, } \\
\text { wettability, and } \\
\text { porosity } \uparrow \text {, } \\
\text { Encapsulation } \\
\text { efficiency } \uparrow \text {, } \\
\text { Oxidative stability } \uparrow\end{array}$ & & [13] \\
\hline $\begin{array}{l}\text { Yeast cells with hydroxypropyl methyl } \\
\text { cellulose }\end{array}$ & Fish oil & Freeze-drying & $\begin{array}{l}\text { External surface of the } \\
\quad \text { microcapsules } \downarrow \text {, } \\
\text { Oxygen diffusion rate } \downarrow\end{array}$ & & {$[14]$} \\
\hline \multicolumn{6}{|l|}{ Chitosan } \\
\hline Chitosan and chitosan/k-carrageenan & $\begin{array}{l}\text { Pimenta dioica essential } \\
\text { oil }\end{array}$ & $\begin{array}{l}\text { Complex } \\
\text { coacervation }\end{array}$ & $\begin{array}{l}\text { The release rate increases } \\
\text { with the chitosan content }\end{array}$ & Antimicrobial & [15] \\
\hline Chitosan and inulin & Lactobacillus casei & $\begin{array}{l}\text { Vibrating } \\
\text { nozzle }\end{array}$ & L. casei survival rate $\uparrow$ & & {$[16]$} \\
\hline Chitosan/xanthan and chitosan/pectin & Palm oil & $\begin{array}{l}\text { Complex } \\
\text { coacervation }\end{array}$ & Controlled release & & [17] \\
\hline $\begin{array}{l}\text { High methoxyl pectin-alginate and } \\
\text { chitosan }\end{array}$ & Kenaf seed oil & Coextrusion & Controlled release & $\begin{array}{l}\text { Increased radical } \\
\text { scavenging } \\
\text { activities and } \\
\text { tocopherols } \\
\text { content }\end{array}$ & {$[18]$} \\
\hline \multicolumn{6}{|l|}{ Pectin } \\
\hline $\begin{array}{l}\text { Pectin and milk protein-carbohydrate } \\
\text { mixture }\end{array}$ & Fish oil & Spray-drying & Oil leakage $\downarrow$ & & {$[19]$} \\
\hline Whey protein hydrolysate/pectin & Fish oil & Spray-drying & $\begin{array}{c}\text { Thickness of the } \\
\text { interfacial layer } \uparrow, \\
\text { Encapsulation efficiency } \uparrow\end{array}$ & $\begin{array}{l}\text { Increased } \\
\text { antioxidant activity }\end{array}$ & {$[20]$} \\
\hline Whey protein isolates and pectin & Anthocyanins & Freeze-drying & $\begin{array}{l}\text { Flavonoid entrapment } \uparrow \text {, } \\
\text { Thermal stability } \uparrow\end{array}$ & Antioxidant & {$[21]$} \\
\hline
\end{tabular}


TABLE 1: Continued.

\begin{tabular}{|c|c|c|c|c|c|}
\hline Wall material & Core material & $\begin{array}{l}\text { Embedding } \\
\text { technology }\end{array}$ & Characteristics & Bioactive effect & Ref. \\
\hline \multicolumn{6}{|l|}{ Starch } \\
\hline Maltodextrin and modified corn starch & Swiss cheese bioaroma & Spray-drying & $\begin{array}{c}\text { Moisture and water } \\
\text { activity } \downarrow\end{array}$ & & [22] \\
\hline $\begin{array}{l}\text { Maltodextrin, gum Arabic, and modified } \\
\text { starch }\end{array}$ & Curcumin & $\begin{array}{l}\text { Spray and } \\
\text { freeze-drying }\end{array}$ & $\begin{array}{l}\text { Curcumin loss and color } \\
\text { change } \downarrow \text {, } \\
\text { Curcumin retention and } \\
\text { stability } \uparrow\end{array}$ & & [23] \\
\hline $\begin{array}{l}\text { Porous starch granules from purple } \\
\text { sweet potato }\end{array}$ & Olive oil & $\begin{array}{l}\text { Osmosis or } \\
\text { diffusion }\end{array}$ & $\begin{array}{c}\text { Adsorption capacity } \uparrow \text {, } \\
\text { Oxidative stability } \uparrow\end{array}$ & & [24] \\
\hline Resistant starch (Hi-maize) & $\begin{array}{l}\text { Lactobacillus } \\
\text { acidophilus }\end{array}$ & Spray-drying & Probiotic survival rate $\uparrow$ & & [25] \\
\hline \multicolumn{6}{|l|}{ Protein } \\
\hline $\begin{array}{l}\text { Dairy proteins mixed with vegetable } \\
\text { proteins }\end{array}$ & Sodium caseinate & Spray-drying & $\begin{array}{c}\text { Droplet size } \downarrow \text {, } \\
\text { Thermal stability } \uparrow, \\
\text { Encapsulation efficiency } \uparrow\end{array}$ & & [26] \\
\hline $\begin{array}{l}\text { Pea protein concentrate, pea protein } \\
\text { isolate, maltodextrin and sodium } \\
\text { carboxymethyl cellulose }\end{array}$ & Conjugated linoleic acid & Spray-drying & $\begin{array}{c}\text { Solubility } \uparrow, \\
\text { Dispersibility } \uparrow, \\
\text { Glass-transition } \\
\text { temperature values } \uparrow\end{array}$ & & [27] \\
\hline $\begin{array}{l}\text { Whey protein concentrate with } \\
\text { mesquite gum }\end{array}$ & Chia oil & Spray-drying & Kinetic parameters $\downarrow$ & Antioxidant & [28] \\
\hline Zein & $\begin{array}{l}\text { Geoffroea decorticans } \\
\text { extract }\end{array}$ & Electrospray & $\begin{array}{l}\text { Water sorption } \uparrow \text {, } \\
\text { Release properties } \uparrow\end{array}$ & $\begin{array}{l}\text { Inhibitory activity } \\
\text { on metabolic } \\
\text { syndrome enzymes }\end{array}$ & {$[29]$} \\
\hline \multicolumn{6}{|l|}{ Composite materials } \\
\hline Alginate, pectin and gelatin complexes & $\begin{array}{l}\text { Lactobacillus plantarum } \\
\text { and DHA-rich oil }\end{array}$ & Freeze-drying & $\begin{array}{c}\text { Smoothness and } \\
\text { compactness of the } \\
\text { particle surface } \uparrow, \\
\text { Thermal stability } \uparrow\end{array}$ & $\begin{array}{l}\text { Higher } \\
\text { survivability of } \\
\text { encapsulated } \\
\text { probiotics }\end{array}$ & {$[30]$} \\
\hline $\begin{array}{l}\text { Chitosan/sodium tripolyphosphate, } \\
\text { chitosan/carboxymethyl cellulose }\end{array}$ & Carotenoids & $\begin{array}{l}\text { Complex } \\
\text { coacervation }\end{array}$ & $\begin{array}{c}\text { Controlled release, } \\
\text { Encapsulation efficiency } \uparrow\end{array}$ & & [31] \\
\hline $\begin{array}{l}\text { Gum Arabic and modified starch } \\
\text { together with either whey protein } \\
\text { concentrate or soy protein isolate }\end{array}$ & Jussara pulp & Spray-drying & $\begin{array}{c}\text { Process yield } \uparrow, \\
\text { Solubility } \uparrow, \\
\text { Total anthocyanin } \\
\text { retention } \uparrow, \\
\text { Encapsulation efficiency } \uparrow\end{array}$ & & [32] \\
\hline $\begin{array}{l}\text { Gum Arabic, maltodextrin, and cellulose } \\
\text { nanofibrils }\end{array}$ & $\begin{array}{l}\text { Sweet orange } \\
\text { essential oil }\end{array}$ & Spray-drying & $\begin{array}{c}\text { Emulsion viscosity } \uparrow \text {, } \\
\text { The droplet size } \downarrow \text {, } \\
\text { Release rate } \uparrow \text {, } \\
\text { Encapsulation efficiency } \uparrow\end{array}$ & & [33] \\
\hline
\end{tabular}

HPMC promoted agglomeration, which reduced the outer surface of microcapsules, and decreased the oxygen diffusion rate [14].

2.2. Chitosan. Chitosan is the second richest biological polysaccharide in nature, inferior to cellulose, mainly distributes in the shell of shrimp and crab or cell wall of algae and fungi and is one of the most commonly used wall materials in the preparation of microencapsulation. The character of containing free amino group makes the chitosan the only basic polysaccharide among natural polysaccharides. And chitosan has many unique properties such as biodegradability, biocompatibility, and osmotic enhancement effects [36]. Chitosan, nontoxic and biodegradable, is a cationic polymer possessing strong antibacterial and antioxidant properties, thus is widely used in fresh fruit and vegetable, food additive, and even cosmetics, medicals, etc. [37].

For instance, chitosan coating improved the survival of probiotic Lactobacillus casei (only 2.7-2.9 logs reduction) and long-chain inulin (2.7 log reduction) under simulative gastrointestinal solution and better kept the size of micro particles while that of alginate beads was significantly decreased by $0.2 \mathrm{~mm}$ [16]. The protection effect might be explained by the electrostatic interactions between chitosan and alginate beads, which blocked gastric juices [16]. Besides, the addition of chitosan into microencapsulated alginate matrix improved the tolerance of Lactobacillus reuteri DSM 17938 against stress conditions during food processing, so 
as to better maintain its microcapsule morphology and cell vitality after freeze-drying [38]. Lavinia-Florina et al. [39] reviewed in detail the application of chitosan in probiotic embedding products, focusing on cell survival, protection performance, and application.

Chew et al. [18] investigated the response of antioxidant activities and biological compounds in microencapsulated kenaf seed oil before and after in vitro simulated digestion, and results showed that the chitosan-coated microcapsule exhibited significantly higher DPPH (145.1\%), ABTS (120.9\%) scavenging activity, and vitamin E content (32.1\%) than that of the noncoated microcapsule. In addition, chitosan can be hydrolyzed/digested by trypsin and lipase (mainly in the small intestine), contributing to the release of encapsulated substances [18]. Similarly, both enhanced antioxidant capacity and less loss of active ingredients were achieved in chitosanmicroencapsulated palm oil, which contained a high content of carotenoid [17, 40]. Furthermore, it was evident that the chitosan microsphere-encapsulated $P$. dioica essential oil presented antibacterial effects against Bacillus cereus, Bacillus subtilis, and Candida utilis due to the antimicrobial activity of chitosan itself [40].

2.3. Alginates. Alginate is a natural polysaccharide and combines with various cations in seawater to form various alginate salts. Alginate is popularly applied in the development of controlled release system and microencapsulation technology due to its great thickening, flocculability, film-forming property, stability, chelation, and biocompatibility, as well as mild reaction conditions, nontoxic and harmless characteristics, simple gelatinization process, and low cost [34].

Sodium alginate is easily soluble in water but forms a gel when meeting the calcium ions, which offers a promising material for microencapsulation. Grape wastes rich in polyphenols were microencapsulated in calcium-alginate beads with optimized vibration nozzle and showed higher stability than nonencapsulated ones [7]. Compared with low molecular weight alginate, microcapsules made of high molecular weight alginate have higher encapsulation efficiency, but they are also bigger in size and release the active constituents much more slowly [7]. Therefore, low molecular weight alginates are more suitable for the occasion when the degradation of active constituents must be avoided, but their rapid release is desirable [7]. Besides, the alginate-based microencapsulated phenolic extracts of Clitoria ternatea (CT) petal flower had smooth surface with the maximal encapsulation efficiency of $84 \%$ under $1.5 \%$ alginate and $3 \% \mathrm{CaCl}_{2}$ conditions [41]. Higher polyphenol content was maintained, with the improved antioxidant capacity and thermal stability (at $188^{\circ} \mathrm{C}$ ), as well as the inhibited pancreatic $\alpha$-amylase activity, in this microcapsule after simulated gastrointestinal digestion [41]. A differential scanning calorimetry (DSC) test found that the interaction between alginate and CT enhanced the thermal stability of CT [41]. In addition, the enhanced tolerance in response to severe environmental conditions was achieved by microencapsulated probiotics Lactobacillus reuteri DSM 17938 in freeze-dried skim milk [38], Lactococcus lactis subsp. cremoris LM0230 in functional food [42] and Lactobacillus rhamnosus NRRL 442 exposed to heat stress
[9]. A higher concentration of sodium alginate minimized the free volume of the microcapsules, thus reduced the thermal permeability [9].

Fioramonti et al. reported that the emulsion stability was affected by the $\mathrm{pH}$ value of solution and the initial sodium alginate concentration due to the electrostatic adsorption between whey protein isolate (charge differently at different $\mathrm{pH}$ ) and negatively charged sodium alginate [43]. The optimal condition for linseed oil (rich in high unsaturated fatty acids) microencapsulation was $0.25 \%$ initial sodium alginate at $\mathrm{pH} 5.0$ where no phase separation and coacervate formation was found [43]. Furthermore, the maximum release rate of spray-dried coriander essential oil embedded in chitosan was at $\mathrm{pH} 2.5$, while that of alginate was at $\mathrm{pH} 6.5$ [6].

2.4. Starch and Its Hydrolysates. A series of starch hydrolysates can be obtained with acid or amylase treatment. Dextrose equivalent $(\mathrm{DE})$ value was reported to demonstrate the degree of hydrolysis or saccharification of starch and affect the viscosity, browning, and oxidation resistance of starch hydrolysates. Maltodextrin and corn syrup are two commonly used microcapsule wall materials, whose DE values are $<20$ and $>20$, respectively [44]. Porous starch is a kind of hollow particle (looks like honeycomb), which have great adsorbability and can contain various substances.

Olive oil microencapsulated with the porous starch prepared from purple sweet potato exhibited higher loading rate and oxidative stability than those of free olive oil, and the best adsorption capacity of porous starch was obtained at $45^{\circ} \mathrm{C}$ and $\mathrm{pH} 5.0$ with reaction for 12 hours [24]. Maltodextrin-microencapsulated saffron and beetroot pigment extracts showed effective heat protection during storage with the average half-life period of 60.03 and 53.03 weeks, respectively [45].

It is widely known that the natural starch is insoluble in cold water, easy to retrogradation and dehydration, and poor in emulsification, while the modified starch improves its properties to widen its application. Curcumin yellow dye was an antioxidant easily degraded in response to light and oxidation stress, but the ternary mixture of maltodextrin, gum Arabic, and modified starch-encapsulated curcumin yellow dye still maintained a high retention rate after spraydrying or freeze-drying and light exposure [23]. In addition, the probiotics Lactobacillus acidophilus in microcapsule added with $1 \%$ resistant starch (Hi-maize) possessed smaller size $(78.49 \mu \mathrm{m})$ than that in the sole alginate microcapsule $(114.51 \mu \mathrm{m})$, while Hi-maize offered better protection for the probiotics exposed to the simulated gastrointestinal juice [25]. It was reported that the iron microcapsule embedded in the mixture of gum Arabic, maltodextrin, and modified starch at the ratio of $4: 1: 1$ had the optimal encapsulation efficiency of $91.58 \%$ and particle stability; also, the significantly higher iron bioavailability in vitro was detected in microcapsule than that in the unencapsulated or in iron salt fortified milk [46]. It was reported that 50\% modified starch-encapsulated Swiss cheese bioaroma had lower the moisture and water activity, which might be attributed to the reduced water diffusion by increasing viscosity with higher concentration of modified starch. 
Also, the concentration of modified starch was positively correlated with the bulk density and average particle diameter [22].

2.5. Pectin. Natural pectin, widely exists in plant roots, stems, leaves, and fruits, is one of the components of the plant cell wall. The main component of pectin is partially methylated $\alpha$-1,4-D-polygalacturonic acid, whose residual carboxyl units existed in the form of free acids or salts of ammonium, potassium, sodium, and calcium. Pectin has a good gelatinization and emulsification stability, widely applied in the food industry, such as ice cream, jam, and fruit juice gelatinization, and the gelatinization mechanism varies with different degree of esterification of pectin to match various characteristics $(\mathrm{pH}$ sugar concentration, etc.) of food gels [47].

Sanguansri et al. [19] reported that both the addition of pectin and heat treatment at $\mathrm{pH} 3$ could reduce the surface oil and free oil of spray-dried fish oil powder and also lessen the oil leakage during powder compression, because a protective layer can be formed around the positively charged oil-water interface by adding the negatively charged pectin to a heated, positively charged stable emulsion. However, additional heat treatment of pectin-free emulsion at low $\mathrm{pH}$ resulted in greater loss of eicosapentaenoic acid (EPA) and docosahexaenoic acid (DHA) in powder, since heating facilitated proteolysis and increased polydispersity [19]. Additionally, by using the layer-by-layer technology, the pectin was attached to the protein monolayer emulsions of fish oil microcapsule through the electrostatic interactions and reinforced the microencapsulation efficiency to $95.2 \%$ [20]. Although the addition of pectin increased the thickness of interface layer, the antioxidant effect and stability of the microcapsule was enhanced because of the inhibition of lipid oxidation [20]. Besides, pectin, as the wall material, protected the multicomponent carriers of microencapsulated hydrophobic and hydrophilic active substances from oxidation or degradation by oxygen or water [48]. Stănciuc et al. [21] embedded the grape anthocyanin extract with whey protein isolates and two different polysaccharides (acacia gum and pectin), and the encapsulation efficiency was up to $94 \%-99 \%$ after freeze-drying. The laser confocal scanning microscope observation showed that the addition of pectin contributed to the smaller particles, and the variant $\mathrm{Cu}$ pectin retained more flavonoids in microcapsules, leading to higher antioxidant activities; and results of the thermal stability study indicated that the pectin had a better protective effect against the anthocyanin degradation [21].

2.6. Protein. Protein widely holds processing properties such as solubility and emulsification, as well as the physiological activities of oxidation resistance, good biocompatibility and biodegradability. In addition, the susceptibility to $\mathrm{pH}$ rendered the protein in a great role in strict $\mathrm{pH}$-controlled release conditions [49]. Therefore, protein is another widely used wall material of microcapsules to meet particular situations.

It was reported that microcapsule with sodium caseinate as wall material had a $13.93 \%$ higher retention rate of vitamin A than that with milk protein concentrate, which might be attributed to the excellent emulsification performance and the molecular flexibility of sodium caseinate [26]. Moreover, the combination of sodium caseinate and pea protein isolates as wall materials led to smaller droplet size, better emulsion thermal stability, and the optimal microencapsulation efficiency (96.08\%) [26]. Higher denaturation temperature of pea protein isolates $\left(83.8^{\circ} \mathrm{C}\right)$ contributed to its great thermal stability, while the denaturation temperatures of whey protein and soy protein were only $70^{\circ} \mathrm{C}$ and $68-88^{\circ} \mathrm{C}$, respectively [26]. Oxidation kinetics and thermodynamic analysis indicated that water within the $a_{\mathrm{w}}$ range of 0.614-0.654 acted as the plasticizer in the polymer matrix, preventing oxygen from passing through the pores, thus delaying the oxidation process to improve the stability of the microcapsule in a whey protein concentrate-polysaccharide matrix and to extend the shelf life [28].

Compared with animal protein, which costs more natural resources, plant protein that is more environmental friendly and meets the needs of vegetarians and people who want to lose weight, gradually enters the market [50]. Studies showed that the application of pea protein, soy protein, zein, or other plant protein well maintained the bioactivities of core materials and improved the solubility, dispersibility, stability, and so on [27, 29]. For example, the microcapsule encapsulated with pea protein isolates exhibited smaller size by preventing droplet aggregation, and higher oxidative stability, which possibly resulted from its antioxidant properties [26]. Besides, the hydrogen bonding between the amino group of protein and the hydroxyl groups of the polyphenolic compounds strengthened the compactness of the wall and the core materials [29].

2.7. Composite Materials. The application of a single material is usually limited to its own nature; therefore, it is necessary to add other ingredients to make composite materials to enhance advantages and weaken disadvantages, so as to satisfy various environmental requirements.

Santana et al. (2016) found that the microcapsule made from the ternary formula of gum Arabic and modified starch, together with either whey protein concentrate or soy protein isolate, exhibited higher process yield, solubility, anthocyanin retention rate, and encapsulation efficiency, as well as lower moisture content than that made from pure or binary formulas [32]. The addition of the ternary mixture of gum Arabic, modified starch, and whey protein concentrate with a high molecular weight increased the glass-transition temperature of the powder and decreased its viscosity, so that fewer solids would paste on the dryer chamber wall, which improved the process yield [32]. In addition, cell survival was increased by nearly $40 \%$ in encapsulated microcapsule composite of $1.06 \%$ alginate, $0.55 \%$ pectin, and $0.39 \%$ gelatin, in comparison to the $50.36 \%$ survival of free cells [30]. At high $\mathrm{pH}$, the chain repulsion between the negatively charged deprotonated carboxyl groups in alginate and pectin produced osmotic pressure, leading to an increase in the swelling rate [30]. But the strong hydrogen bonding between the protonated amino group in gelatin and deprotonated carboxyl groups in alginate and pectin well balanced the intermolecular forces to avoid destruction [30]. Higher thermal resistance and 
crystallinity degree were detected in (ovalbumin, pectin, and xanthan gum) microencapsulated sacha inchi oil, indicating better heat stability and structure organization to protect $\omega-3$ in oil [51].

The composition and proportion of microcapsule materials were adjusted to shape different properties, applying in personalized customization. For example, in the sweet orange essential oil microcapsule, the presence of cellulose nanofibrils helped reduce the droplet size and improve the encapsulation efficiency by increasing the emulsion viscosity, but promoted more essential oils release at $25^{\circ} \mathrm{C}$ due to its favorable permeability to liquid, in comparison to the formulation without cellulose nanofibrils [33]. Chitosan/carboxymethyl cellulose encapsulated carotenoid microcapsule showed low release in water and gastric juice which avoided degradation, and also low release in intestinal juice (adverse for absorption). In contrast, the microcapsules encapsulated in chitosan/sodium tripolyphosphate exhibited high release rate in water and gastric juice, and intestinal juice [31]. Similar research was performed on the microencapsulation of palm oil and the release curve revealed that the chitosan/xanthan wall material was more suitable for yoghurt system than chitosan/pectin [17].

FTIR spectra is widely used to investigate the characteristics of molecular structure and is also used to determine the intermolecular forces, including the bonds between wall and core materials, or those among composite materials of microcapsule, such as hydrogen and Van der Waals bonds [30], electrostatic interactions [52], and $\mathrm{Ca}^{2+}$ complexation [8]. However, the lack of structure-activity relationship studies remains to be a major barrier in microcapsule application. That is why there were lots of research on microencapsulation with composite materials, but much fewer were actually applied in market production. It might be a promising solution to design the microparticles according to corresponding delivery process in desperate need of further study on molecular mechanism. Moreover, it is of great significance to establish a database to sort out and summarize the current researches on microcapsules, including the properties of various materials and the interactions and effects of these materials in different occasions. Then, the researchers can customize the microcapsules according to their use to match the suitable wall material and give full play to the advantages of different ingredients.

2.8. Yeast Cells. Yeast cells, which are light in color and smell, disperse well in water, have strong adaptability to environment, and can be cultured on a large scale. Their natural eukaryotic cell structure makes them potential for material embedding. These characteristics of yeast cells offer advantages that other microcapsule wall materials cannot match: (1) the natural double-layer cyst structure formed from the outer cell wall and inner cell membrane of yeast cells can avoid volatilization loss of aromatic substances and oxidative deterioration from environmental light or oxygen invasion [53]. (2) No requirement of any other additives during the preparation of microcapsules (only yeast cells, core substances to be embedded, and solvents are needed to contact at high frequency) [14]. (3) Easy release of core substances: once meeting the wet mucosa such as tongue or nose mucosa, flavor substances or other active components can be released without breaking the wall. Yeast cells' natural biological adhesion provided a long-term release for flavor substances. (4) The nonthermoelastic cavity structure ensures that the wrapped core material will not be damaged by heat extrusion, roasting, frying, or boiling in the food processing. The $\beta$-glucan, which supports the physical strength of the cell wall, is difficult to break down and protects the core substance from pressure heating or freezing treatments [54]. (5) Yeast cells, safe and nontoxic, are easy to culture, thus have become an economical and eco-friendly microcapsule wall material.

For example, two flavors (D-limonene and ethyl hexanoate) in the yeast retained almost $85 \%$ after $1 \mathrm{~h}$ dry heating at $140^{\circ} \mathrm{C}$, and thermogravimetric analysis suggested that the yeast cell wall would not break until a temperature above $260^{\circ} \mathrm{C}$ [54]. However, flavors were rapidly released once water was added to the powder, because hard $\beta$-glucans became soft and soluble under wet conditions and turned into a gelatinized solution [54].

\section{Applications in Food Industry}

3.1. Applications in Plant-Derived Food. With the improvement of people's living standard and the pursuit of healthy life quality, health-promoting and environmental friendly plant-derived food will have a larger m4arket. At present, there have been a few studies on the application of microcapsules in baking, fruit/vegetable juice, or other plant foods to enhance the nutrition.

Umesha et al. found that the addition of microencapsulated garden cress seed oil protected $\alpha$-linolenic acid against the oxidation in biscuits to prolong its shelf life [55]. The Garcinia cowa fruit extract rich in hydroxycitric acid, which is health-promoting but hygroscopic and thermosensitive, was protected by microencapsulated powder using whey protein concentrate and was incorporated into bread baking [56]. Among three microcapsules with different wall materials (whey protein isolate, maltodextrin, and a composite of both), the whey protein isolate exhibited higher encapsulation efficiency during the baking process. Besides, the bread with whey protein isolate-encapsulated Garcinia cowa fruit extract showed softer, lighter-texture, more desirable color and organoleptic properties, and higher free hydroxycitric acid concentration [56]. Furthermore, the pasta with microencapsulated hydroxycitric acid by spray-drying had higher antioxidant ability and sensory characteristics [57].

It was reported that passion fruit juice encapsulated in $n$-octenylsuccinate-derivatised starch retained over $70 \%$ of vitamin $\mathrm{C}$ after 77 days of storage at 7 or $25^{\circ} \mathrm{C}$ [58]. Alginate microbeads were effective in reducing the acidification and improving the sensory properties of fruit-based foods during storage [59]. In addition, the microencapsulation of allyl isothiocyanate (resistant to pathogenic fungi but irritating) effectively controlled its release rate to relieve irritation. And its application on fresh tomato significantly reduced the decay rate and weight loss, thus prolonged the shelf life of fresh products [60]. Microencapsulation was also a promising alternative to improve the stability 
of polyphenols, pigments, and nutrients in fruit-based food [61-63]. It was evident that the microcapsule of maltodextrin and Arabic gum maintained the anthocyanin content up to $150 \mathrm{mg} 100 \mathrm{~g}^{-1}$, over $80 \%$ of the initial concentration in juçara fruit pulp [63]. Interestingly, the microencapsulated alginate beads (Lactobacillus plantarum HER1325) prevented bacteriophage infections during vegetable fermentation [64].

3.2. Applications in Animal-Derived Food. Compared with plant-derived food, microencapsulation technology is more applied in animal-derived food, especially in antiseptic and antimicrobial properties of meat products and probiotics maintenance in dairy products.

Microencapsulated clove oil might be an alternative preservative with antimicrobial effect, and only $0.070 \%$ of addition could reduce the disease index and mold spore variation rate, which made it effective for cooked meat products [65]. Although nisin has antibacterial activity, but no free nisin was available after 28 days of storage at $4^{\circ} \mathrm{C}$. It was reported that the nisin microencapsulated in alginate-cellulose beads was evident to maintain half of the initial concentration of nisin $\left(63 \mu \mathrm{g} \mathrm{mL}^{-1}\right)$, which significantly reduced the number of Listeria monocytogenes in ready-to-eat ham and did not change the $\mathrm{pH}$ and the color [66]. Furthermore, lower fat content and energy value and higher protein concentration were detected in sausage, partially replaced with microencapsulated fish oil [67]. Besides, better preserved EPA and DHA, oxidation protection, and healthier polyunsaturated/saturated fat ratio were achieved by microencapsulation which reduced the atherogenicity and thrombogenicity traits [68-70].

Microencapsulation technology was also widely used in dairy products, especially in yogurt, in order to improve the vitality of probiotics in lower $\mathrm{pH}$ environment [71], resist gastric juice [72], inhibit postacidification [73], and release microbial cells in the intestinal environment to increase the bioavailability $[74,75]$. Lactobacillus paracasei subsp. paracasei and Lactobacillus paraplantarum microencapsulated with whey protein isolate and gum Arabic by complex coacervation exhibited significantly higher viability in simulated gastric juice (from 19\% to $73 \%$ ) and higher survival rate (from $59 \%$ to $86 \%$ ) after 60 days of storage at $4^{\circ} \mathrm{C}$ than nonencapsulated cells [74]. Results demonstrated that the polyphenol extract microcapsule obtained by freeze-drying method had higher stability than that by spray-drying method, and the $\mathrm{pH}$, titratable acid, viscosity, or other physiochemical properties of the supplemented yogurt were less affected [76]. Penhasi microencapsulated Bifidobacterium animalis spp. lactis in a double-layer capsule with the smart coating of hydroxypropyl cellulose and hydroxypropyl methyl cellulose for powdered infant formula [35]. The polymer formed a gel structure around the bacterial core to prevent heat and humidity from reaching the core materials and to protect the bacteria [35].

Excitingly, a research confirmed the specific interactions between the bacteria and whey protein, and that the pilus played a crucial role in the localization of bacteria in the microparticles. On the contrary, the encapsulation efficiency of the mutant lacking pili decreased significantly [77]. This discovery provided a new insight into the molecular mechanism of the embedding of probiotics [77].

3.3. Additives. Except for plant-derived food and animalderived food, microencapsulation is also widely applied in food additives to offer food attractive appearance and fragrance to satisfy market requirement. Aromatic substances (D-limonene and ethyl hexanoate) coated with yeast powder had higher oxidation stability than that coated with maltodextrin [54]. Moreover, the presence of cyclodextrin entrapped volatiles and well maintained the strawberry flavor in response to the environment stress stimuli [78]. Estevinho and his colleagues produced flavor microparticles encapsulated in water-soluble chitosan by spray-drying, and the particle less than $100 \mu \mathrm{m}$ in size with smooth spherical surface was obtained [79]. The mussel protein hydrolysate had bitter taste because of the hydrophobic amino acids produced during protein hydrolysis, but the bitterness was well covered up by microencapsulation to improve the sensory acceptance [80]. Similarly, unpleasant taste and odor of isoflavone added in the beverages were masked by being microencapsulated in inulin and maltodextrin [81]. Then, the microencapsulated isoflavone was gradually released during simulated digestion [81]. In addition, hibiscus extract rich in anthocyanins was a natural colorant but sensitive to light, heat, and oxygen. Microencapsulation through dripping-extrusion or atomization effectively increased the stability of anthocyanin during food processing and storage [82]. Furthermore, the controlled release achieved by microencapsulation offered a long duration of flavor in chewing gum [83]. Due to the high cost and technical constraints, the application of microcapsule technology in everyday condiments is still under research in the laboratory stage. But microcapsule technology has already commonly appeared in the fortified food market, such as Capsulae (France), Microtek Laboratories, Inc. (U.S.), Aveka, Inc. (U.S.), TasteTech Ltd. (U.K.), LycoRed Ltd. (Israel), and Innobio Limited (China), which are top companies in microencapsulation market involved in food industry [84].

\section{Microencapsulation Techniques}

The publications of commonly used microcapsule embedding technologies from 2010 to the end of 2019 are shown in Figure 2. Apparently, "spray-drying" came first by a landslide, accounting for almost a third of all publications, followed by "emulsification," "freeze-drying," and "coacervation." Next, the advantages and disadvantages of several top published embedding techniques are presented below.

4.1. Spray-Drying Technique. Spray-drying microencapsulation is to atomize the emulsion of wall material and core material in the dry and high-temperature environment, which evaporates the moisture via heat exchange between the droplets and the drying medium and solidifies the shell of droplet quickly to wrap the core material. This coating method, the most widely used embedding technology, is characterized by low cost (30-50 times lower than freezedrying), simple operation, continuous production, and 


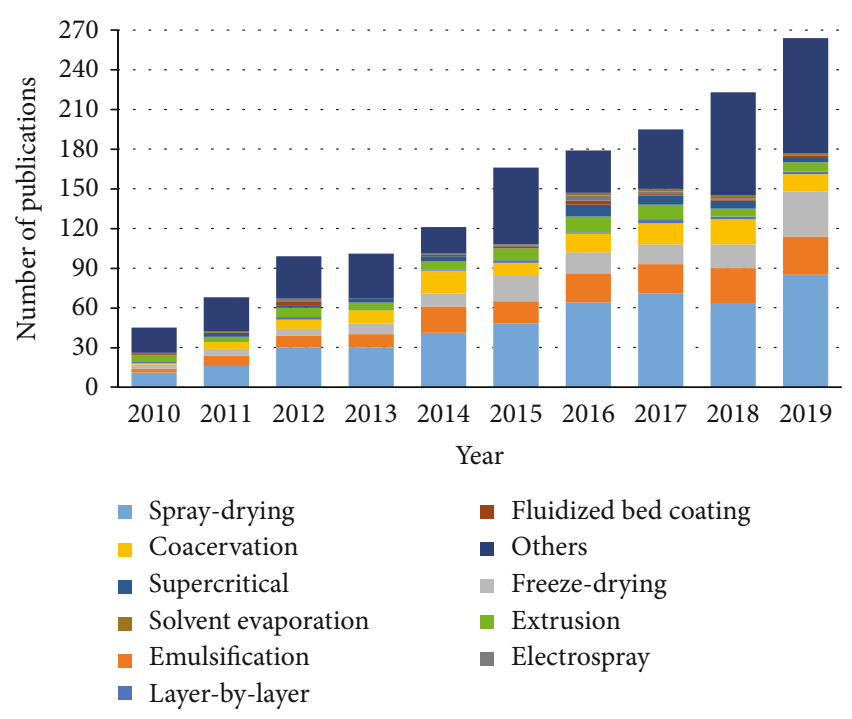

Figure 2: Number of literatures published from 2010 to 2019 regarding microencapsulation technology development on food science and engineering (obtained on Scopus, June, 2020; common keyword: "microencapsulation" and "food").

suitability for mass production [4]. However, during the preparation process, the core material should be in the high-temperature airflow, where the active substances are easy to be inactivated, resulting in lower embedding rate and coating efficiency [4]. Besides, spray-drying method requires that wall materials have good water solubility, low viscosity, and good fluidity, so only few wall materials can be used for spray-drying, such as Arabic gum and modified starch, which limit the application of spray-drying [3]. Moreover, low water evaporation brings about agglomeration or hardening, whereas the excessive water evaporation leads to cracks in the wall material and reduced compactness. Several studies combining spray-drying with vacuumdrying or freeze-drying improved the embedding efficiency of probiotics or other heat-sensitive materials but also increased the production cost [85].

4.2. Emulsification Technique. Emulsification is a chemical embedding method in which the mixture of core material and wall material (dispersed phase) is added into a large number of vegetable oil (continuous phase), containing the emulsifier to form a stable emulsion and microencapsulate under the action of cross-linking agent. Although the high survival rate and simplicity of encapsulated probiotics, the feasible preparation process was achieved by this method, and the production cost was usually very high because of the large amount of vegetable oil required [5].

4.3. Freeze-Drying Technique. Freeze-drying is a method of sublimating the ice into vapor under high-vacuum condition after quick freeze. The ice sublimation removes heat and keeps the whole process cool, which preserves the activity of some biological samples, such as proteins. However, the formation of ice crystals during freezing process and the high osmotic pressure during dehydration might destroy the integrity of the microbial cell membrane; therefore, the hydrophilic substance is usually added into the system as the cryoprotectant [86]. Due to the high-cost limitation, freeze-drying technique is more used for heat-sensitive food with high value.

4.4. Coacervation Technique. The core material is emulsified or suspended in the solution of wall material, and then another substance or solvent is added to reduce the solubility of the wall material, which is evenly aggregated and surrounded by the core material to form microcapsules. The coacervation technique includes the complex condensation and the single condensation. In the complex coacervation, two materials with opposite charges are used as wall materials, and the core materials are emulsified and dispersed in the wall materials solution. By regulating the $\mathrm{pH}$, temperature, or concentration of aqueous solution of the system, the two wall materials are aggregated with the core material through the interaction between the opposite charges to form microcapsules [87]. Complex coacervation is a commonly used technique for embedding fat-soluble food ingredients with advantages of no need of special equipment, mild process conditions, less damage to core material quality, and higher product encapsulation efficiency, as well as the better antioxidation and release controlling properties. Gelatin and gum Arabic wall materials are more applied in the microcapsule preparation by coacervation method $[88,89]$. The main disadvantages of coacervation technique are high cost, a lot of coagulants consumed, difficult to control the conditions of coacervation reaction, fewer coagulants available for wall materials, and easily produced chemical residue during processing [3]. Due to these shortcomings, this technique is still at the experimental stage and has not been widely applied in food industry. However, it is still a potential technique due to the great release control ability.

4.5. Layer-by-Layer (LBL) Assembly Technique. Layer-bylayer (LBL) self-assembly is a process in which layers are spontaneously attached with each other to form the stable molecular aggregates or supramolecular structures which possess specific functions or performances by noncovalent interactions, like electrostatic attraction, hydrogen bond, and coordination bond. LBL assembly technology does well in controlling the size, shape, composition, thickness, and structure of the capsule on the nanometer scale accurately $[90,91]$. Therefore, LBL assembly technology is a promising method for the preparation of multilayer microcapsules matching variable environment [90]. However, the preparation process of LBL self-assembly, where multiple wall materials with different charges are needed, takes a long time; therefore, this technique is not suitable in mass rapid production yet. Moreover, the insufficient stability of LBL assembly that resulted from the weak interactions may impact the product quality.

4.6. Extrusion Technique. Extrusion is a physical embedding method for forming microcapsules by squeezing core material and colloid mixture into the hardening bath in the form of the liquid drops through the needle tube under pressure. 
The cost is more than twice as much as the spray-drying, but this technique could effectively protect oil from volatilization and oxygen to significantly extend the shelf life of products due to its small surface area of micropores [3]. However, the low production rate could not meet the demand of large-scale production in industrial application, and the large particle size affects its taste [47]. And carbohydrates that could form glassy structures are commonly used as wall materials [92]. Extrusion technique is commonly used for embedding all kinds of volatile, vitamin, and pigment compounds or other heat-sensitive materials.

4.7. Supercritical Technique. The nonvolatile substance is dissolved in the supercritical fluid, which could rapidly expand in a very short time when decompressed through the pore capillary, so that the solute oversaturates and a large number of fine particles are formed. By controlling the experimental conditions, the hollow microcapsules with a certain particle size could be precipitated and separated [93]. Then, the generated hollow microcapsules and the core material collide with each other frequently and evenly wrapped together. Afterwards, the microcapsule product could be obtained after removing the unembedded core material [93]. Among the supercritical fluid, the supercritical $\mathrm{CO}_{2}$ is most widely applied because of the low critical temperature, low viscosity, high solvent, high dispersion, high mass transfer, and nontoxicity. Usually, the supercritical $\mathrm{CO}_{2}$ to prepare microcapsules requires almost no organic solvents, green and environmentally friendly, and the resulting product has a small particle size and is suitable for heat-sensitive substances [93]. In addition, hydrophobic or hydrophilic materials that can be dissolved in $\mathrm{CO}_{2}$ can be used as microcapsule wall materials [94]. However, the solubility of $\mathrm{CO}_{2}$ to different solutes varies greatly, and materials with low boiling point, low polarity, or low molecular weight are generally more suitable [94].

4.8. Electrospray Technique. Electrospray is to decompose the polymer fluid transported by the conductive capillary pump into the fine droplets through a high-voltage electric field [95]. After the solvent evaporates, the polymer particles are generated and collected on the metal collector to obtain microcapsules [95]. This electrospray technique does not require additional reaction solvent and could be realized in one-step and eco-friendly [96]. Microcapsules prepared by electrostatic spray are homogeneous and nanometer in size, which has attracted more and more attention [5]. The electrospray technology has widely been applied in the pharmaceutical industry and has great potential in the encapsulation of bioactive substances, volatile compounds, sustained-release preservatives, and functional foods in food industry [5].

4.9. Nanocapsulation Technique. With the development of microcapsule technology, the particle size of microcapsule can reach the nanoscale, that is, the nanocapsule. Nanocapsule is characterized by a small particle size, large specific surface area, and easy formation of uniform and stable colloidal solution. Besides inheriting the advantages of ordinary microcapsules, nanocapsules are smaller in size, which can increase the adhesion of active substances to tissues, so they effectively improve the bioavailability of nutrients in functional foods [97]. Nanocapsules can also penetrate through capillaries, penetrate into tissues, and be absorbed by cells, thus enabling more precise targeting of the core materials [98]. Therefore, nanocapsule has become an emerging direction in the microcapsule research field.

Compared with ordinary microcapsules with particle size in microns, nanocapsules have higher requirements on particle size; thus, nanocapsules need additional special treatments, usually high energy, based on the preparation of ordinary capsules, such as ultrasound, high pressure, or intense mechanical agitation $[5,93]$.

\section{Conclusions}

This paper offers an overview on the recent development of microencapsulation in food industry, especially the advances in polymer wall materials, food applications, and embedding technologies. Microencapsulation technology is mainly applied in the delivery of functional ingredients, which contributed to the extension of shelf life, the enhancement of thermal stability, the inhibition of pathogenic microorganism development, the enrichment of nutrition, the controlled release, etc. A variety of materials were used to prepare microcapsules, including polysaccharides, proteins, and other rich natural sources. And the composite materials were increasingly attractive to meet the needs of different delivery systems in response to various environmental stress stimuli. A database can be built based on the characteristics of different wall materials and various microencapsulation techniques to help/guide researchers to design and produce suitable microcapsules. Moreover, microencapsulation was widely used in animal-derived food, including dairy and meat, and plant-derived food, especially the preservation of fresh fruits and vegetables or color-protection in baking. Besides, additives with microencapsulation got further progressed and wider application. Among the microencapsulation technologies, the spray-drying technique was ranked first for the low cost and suitability for large-scale production. However, other novel techniques free from environmental pollution, such as the LBL self-assembly and electrospray, are potential and likely to be new directions in the future.

\section{Conflicts of Interest}

The authors declare that there is no conflict of interest regarding the publication of this paper.

\section{Acknowledgments}

This work was supported by the Key Laboratory of AgroProducts Postharvest Handling (KLAPPH2019-03) and Key Laboratory of Storage of Agricultural Products, Ministry of Agriculture and Rural Affairs. 


\section{References}

[1] Grand View Research, Microencapsulation market size, share \& trends analysis report by technology (emulsion, spray), by application (pharmaceutical, home \& personal care), by coating material, and segment forecasts, 2019 - 20252019, https://www .grandviewresearch.com/industry-analysis / microencapsulation-market.

[2] V. Đorđević, B. Balanč, A. Belščak-Cvitanović et al., "Trends in encapsulation technologies for delivery of food bioactive compounds," Food Engineering Reviews, vol. 7, pp. 452-490, 2014.

[3] K. G. H. Desai and H. Jin Park, "Recent developments in microencapsulation of food ingredients," Drying Technology, vol. 23, no. 7, pp. 1361-1394, 2005.

[4] A. M. Bakry, S. Abbas, B. Ali et al., "Microencapsulation of oils: a comprehensive review of benefits, techniques, and applications," Comprehensive Reviews in Food Science and Food Safety, vol. 15, no. 1, pp. 143-182, 2016.

[5] J. A. Tapia-Hernández, P. I. Torres-Chávez, B. Ramírez-Wong et al., "Micro- and nanoparticles by electrospray: advances and applications in foods," Journal of Agricultural and Food Chemistry, vol. 63, no. 19, pp. 4699-4707, 2015.

[6] C. Dima, L. Pătraşcu, A. Cantaragiu, P. Alexe, and Ş. Dima, "The kinetics of the swelling process and the release mechanisms of_Coriandrum sativum_L. essential oil from chitosan/alginate/inulin microcapsules," Food Chemistry, vol. 195, pp. 39-48, 2016.

[7] O. Aizpurua-Olaizola, P. Navarro, A. Vallejo, M. Olivares, N. Etxebarria, and A. Usobiaga, "Microencapsulation and storage stability of polyphenols from Vitis vinifera grape wastes," Food Chemistry, vol. 190, pp. 614-621, 2016.

[8] C. C. Coghetto, G. B. Brinques, N. M. Siqueira, J. Pletsch, R. M. D. Soares, and M. A. Z. Ayub, "Electrospraying microencapsulation of Lactobacillus plantarum enhances cell viability under refrigeration storage and simulated gastric and intestinal fluids," Journal of Functional Foods, vol. 24, pp. 316-326, 2016.

[9] S. Shaharuddin and I. I. Muhamad, "Microencapsulation of alginate-immobilized bagasse with Lactobacillus rhamnosus NRRL 442: enhancement of survivability and thermotolerance," Carbohydrate Polymers, vol. 119, pp. 173-181, 2015.

[10] I. M. Fareez, S. M. Lim, N. A. A. Zulkefli, R. K. Mishra, and K. Ramasamy, "Cellulose derivatives enhanced stability of alginate-based beads loaded with Lactobacillus plantarum LAB12 against low $\mathrm{pH}$, high temperature and prolonged storage," Probiotics and Antimicrobial Proteins, vol. 10, no. 3, pp. 543-557, 2018.

[11] A. M. Bakry, Z. Fang, Y. Ni, H. Cheng, Y. Q. Chen, and L. Liang, "Stability of tuna oil and tuna oil/peppermint oil blend microencapsulated using whey protein isolate in combination with carboxymethyl cellulose or pullulan," Food Hydrocolloids, vol. 60, pp. 559-571, 2016.

[12] Z. Z. Feng, M. Y. Li, Y. T. Wang, and M. J. Zhu, “Astaxanthin from_Phaffia rhodozyma_: Microencapsulation with carboxymethyl cellulose sodium and microcrystalline cellulose and effects of microencapsulated astaxanthin on yogurt properties," LWT, vol. 96, pp. 152-160, 2018.

[13] F. T. Karim, K. Ghafoor, S. Ferdosh et al., "Microencapsulation of fish oil using supercritical antisolvent process," Journal of Food and Drug Analysis, vol. 25, no. 3, pp. 654-666, 2017.

[14] A. Czerniak, P. Kubiak, W. Białas, and T. Jankowski, "Improvement of oxidative stability of menhaden fish oil by microencapsulation within biocapsules formed of yeast cells," Journal of Food Engineering, vol. 167, pp. 2-11, 2015.

[15] C. Dima, M. Cotârlet, P. Alexe, and S. Dima, "Reprint of "Microencapsulation of essential oil of pimento [Pimenta dioica (L) Merr.] by chitosan/k-carrageenan complex coacervation method"," Innovative Food Science \& Emerging Technologies, vol. 25, pp. 97-105, 2014.

[16] P. Darjani, M. Hosseini Nezhad, R. Kadkhodaee, and E. Milani, "Influence of prebiotic and coating materials on morphology and survival of a probiotic strain of_Lactobacillus casei_exposed to simulated gastrointestinal conditions," $L W T$, vol. 73, pp. 162-167, 2016.

[17] J. K. Rutz, C. D. Borges, R. C. Zambiazi, M. M. Crizel-Cardozo, L. S. Kuck, and C. P. Z. Noreña, "Microencapsulation of palm oil by complex coacervation for application in food systems," Food Chemistry, vol. 220, pp. 59-66, 2017.

[18] S. C. Chew, C. P. Tan, K. Long, and K. L. Nyam, "In-vitro evaluation of kenaf seed oil in chitosan coated-high methoxyl pectin-alginate microcapsules," Industrial Crops and Products, vol. 76, pp. 230-236, 2015.

[19] L. Sanguansri, P. Udabage, S. Bhail et al., "Microencapsulated fish oil powder formulation with improved resistance to oil leakage during powder compression," Journal of the American Oil Chemists Society, vol. 93, no. 5, pp. 701-710, 2016.

[20] F. Tamm, C. Härter, A. Brodkorb, and S. Drusch, "Functional and antioxidant properties of whey protein hydrolysate/pectin complexes in emulsions and spray-dried microcapsules," LWT, vol. 73, pp. 524-527, 2016.

[21] N. Stănciuc, M. Turturică, A. M. Oancea et al., "Microencapsulation of anthocyanins from grape skins by whey protein isolates and different polymers," Food and Bioprocess Technology, vol. 10, no. 9, pp. 1715-1726, 2017.

[22] J. M. G. da Costa, E. K. Silva, A. A. C. Toledo Hijo et al., "Microencapsulation of Swiss cheese bioaroma by spray-drying: process optimization and characterization of particles," Powder Technology, vol. 274, pp. 296-304, 2015.

[23] D. M. Cano-Higuita, C. R. Malacrida, and V. R. N. Telis, "Stability of curcumin microencapsulated by spray and freeze drying in binary and ternary matrices of maltodextrin, gum Arabic and modified starch," Journal of Food Processing and Preservation, vol. 39, no. 6, pp. 2049-2060, 2015.

[24] M. Lei, F. C. Jiang, J. Cai et al., "Facile microencapsulation of olive oil in porous starch granules: fabrication, characterization, and oxidative stability," International Journal of Biological Macromolecules, vol. 111, pp. 755-761, 2018.

[25] M. de Araújo Etchepare, G. C. Raddatz, A. J. Cichoski et al., "Effect of resistant starch (Hi-maize) on the survival of _Lactobacillus acidophilus_ microencapsulated with sodium alginate," Journal of Functional Foods, vol. 21, pp. 321329, 2016.

[26] X. Li, Y. Feng, S. Ting, J. Jiang, and Y. Liu, "Correlating emulsion properties to microencapsulation efficacy and nutrients retention in mixed proteins system," Food Research International, vol. 115, pp. 44-53, 2019.

[27] A. M. M. Costa, J. C. Nunes, B. N. B. Lima et al., "Effective stabilization of CLA by microencapsulation in pea protein," Food Chemistry, vol. 168, pp. 157-166, 2015.

[28] L. A. Escalona-García, R. Pedroza-Islas, R. Natividad, M. E. Rodríguez-Huezo, H. Carrillo-Navas, and C. Pérez-Alonso, "Oxidation kinetics and thermodynamic analysis of chia oil microencapsulated in a whey protein concentrate- 
polysaccharide matrix," Journal of Food Engineering, vol. 175, pp. 93-103, 2016.

[29] M. S. Costamagna, L. G. Gómez-Mascaraque, I. C. Zampini et al., "Microencapsulated chañar phenolics: A potential ingredient for functional foods development," Journal of Functional Foods, vol. 37, pp. 523-530, 2017.

[30] A. S. Vaziri, I. Alemzadeh, M. Vossoughi, and A. C. Khorasani, "Co-microencapsulation of Lactobacillus plantarum and DHA fatty acid in alginate-pectin-gelatin biocomposites," Carbohydrate Polymers, vol. 199, pp. 266-275, 2018.

[31] J. K. Rutz, C. D. Borges, R. C. Zambiazi, C. G. da Rosa, and M. M. da Silva, "Elaboration of microparticles of carotenoids from natural and synthetic sources for applications in food," Food Chemistry, vol. 202, pp. 324-333, 2016.

[32] A. A. Santana, D. M. Cano-Higuita, R. A. de Oliveira, and V. R. N. Telis, "Influence of different combinations of wall materials on the microencapsulation of Jussara pulp (Euterpe edulis) by spray drying," Food Chemistry, vol. 212, pp. 1-9, 2016.

[33] H. J. B. de Souza, R. V. de Barros Fernandes, S. V. Borges et al., "Utility of blended polymeric formulations containing cellulose nanofibrils for encapsulation and controlled release of sweet orange essential oil," Food and Bioprocess Technology, vol. 11, no. 6, pp. 1188-1198, 2018.

[34] A. K. Anal and H. Singh, "Recent advances in microencapsulation of probiotics for industrial applications and targeted delivery," Trends in Food Science \& Technology, vol. 18, no. 5, pp. 240-251, 2007.

[35] A. Penhasi, "Microencapsulation of probiotic bacteria using thermo-sensitive sol-gel polymers for powdered infant formula," Journal of Microencapsulation, vol. 32, no. 4, pp. 372$380,2015$.

[36] G. A. Martau, M. Mihai, and D. C. Vodnar, "The use of chitosan, alginate, and pectin in the biomedical and food sectorbiocompatibility, bioadhesiveness, and biodegradability," Polymers, vol. 11, no. 11, p. 1837, 2019.

[37] B. N. Estevinho, F. Rocha, L. Santos, and A. Alves, "Microencapsulation with chitosan by spray drying for industry applications - a review," Trends in Food Science \& Technology, vol. 31, no. 2, pp. 138-155, 2013.

[38] A. De Prisco, D. Maresca, D. Ongeng, and G. Mauriello, "Microencapsulation by vibrating technology of the probiotic strain_Lactobacillus reuteri__DSM 17938 to enhance its survival in foods and in gastrointestinal environment," LWT - Food Science and Technology, vol. 61, no. 2, pp. 452-462, 2015.

[39] L.-F. Călinoiu, B. Ştefănescu, I. Pop, L. Muntean, and D. Vodnar, "Chitosan coating applications in probiotic microencapsulation,” Coatings, vol. 9, no. 3, p. 194, 2019.

[40] C. Dima, M. Cotârlet, P. Alexe, and S. Dima, "Microencapsulation of essential oil of pimento [Pimenta dioica (L) Merr.] by chitosan/k-carrageenan complex coacervation method," Innovative Food Science \& Emerging Technologies, vol. 22, pp. 203-211, 2014.

[41] P. Pasukamonset, O. Kwon, and S. Adisakwattana, "Alginatebased encapsulation of polyphenols from Clitoria ternatea petal flower extract enhances stability and biological activity under simulated gastrointestinal conditions," Food Hydrocolloids, vol. 61, pp. 772-779, 2016.

[42] T. W. Yeung, I. J. Arroyo-Maya, D. J. McClements, and D. A. Sela, "Microencapsulation of probiotics in hydrogel particles: enhancing Lactococcus lactis subsp. cremoris LM0230 viability using calcium alginate beads," Food \& Function, vol. 7, no. 4, pp. 1797-1804, 2016.

[43] S. A. Fioramonti, M. J. Martinez, A. M. R. Pilosof, A. C. Rubiolo, and L. G. Santiago, "Multilayer emulsions as a strategy for linseed oil microencapsulation: effect of $\mathrm{pH}$ and alginate concentration," Food Hydrocolloids, vol. 43, pp. 8-17, 2015.

[44] J. D. Hoyos-Leyva, L. A. Bello-Pérez, J. Alvarez-Ramirez, and H. S. Garcia, "Microencapsulation using starch as wall material: a review," Food Reviews International, vol. 34, pp. 148-161, 2017.

[45] C. Chranioti, A. Nikoloudaki, and C. Tzia, "Saffron and beetroot extracts encapsulated in maltodextrin, gum Arabic, modified starch and chitosan: incorporation in a chewing gum system," Carbohydrate Polymers, vol. 127, pp. 252263, 2015.

[46] C. Gupta, P. Chawla, S. Arora, S. K. Tomar, and A. K. Singh, "Iron microencapsulation with blend of gum Arabic, maltodextrin and modified starch using modified solvent evaporation method - milk fortification," Food Hydrocolloids, vol. 43, pp. 622-628, 2015.

[47] S. Iravani, H. Korbekandi, and S. V. Mirmohammadi, "Technology and potential applications of probiotic encapsulation in fermented milk products," Journal of Food Science and Technology, vol. 52, no. 8, pp. 4679-4696, 2015.

[48] J. Noh, J. Kim, J. S. Kim, Y. S. Chung, S. T. Chang, and J. Park, "Microencapsulation by pectin for multi-components carriers bearing both hydrophobic and hydrophilic active agents," Carbohydrate Polymers, vol. 182, pp. 172-179, 2018.

[49] A. Can Karaca, N. H. Low, and M. T. Nickerson, "Potential use of plant proteins in the microencapsulation of lipophilic materials in foods," Trends in Food Science \& Technology, vol. 42, no. 1, pp. 5-12, 2015.

[50] Z. L. Wan, J. Guo, and X. Q. Yang, "Plant protein-based delivery systems for bioactive ingredients in foods," Food \& Function, vol. 6, no. 9, pp. 2876-2889, 2015.

[51] J. Vicente, T. de Souza Cezarino, L. J. B. Pereira et al., "Microencapsulation of sacha inchi oil using emulsion-based delivery systems," Food Research International, vol. 99, Part 1, pp. 612622, 2017.

[52] M. Hosseinnia, M. A. Khaledabad, and H. Almasi, "Optimization of Ziziphora clinopodiodes essential oil microencapsulation by whey protein isolate and pectin: a comparative study," International Journal of Biological Macromolecules, vol. 101, pp. 958-966, 2017.

[53] M. Feuillat, "Yeast macromolecules: origin, composition, and enological interest," American Journal of Enology and Viticulture, vol. 54, pp. 211-213, 2003.

[54] A. Sultana, Y. Tanaka, Y. Fushimi, and H. Yoshii, "Stability and release behavior of encapsulated flavor from spray-dried Saccharomyces cerevisiae and maltodextrin powder," Food Research International, vol. 106, pp. 809-816, 2018.

[55] S. S. Umesha, R. S. Manohar, A. R. Indiramma, S. Akshitha, and K. A. Naidu, "Enrichment of biscuits with microencapsulated omega-3 fatty acid (alpha-linolenic acid) rich garden cress (Lepidium sativum) seed oil: physical, sensory and storage quality characteristics of biscuits," LWT - Food Science and Technology, vol. 62, no. 1, pp. 654-661, 2015.

[56] P. N. Ezhilarasi, D. Indrani, B. S. Jena, and C. Anandharamakrishnan, "Freeze drying technique for microencapsulation of Garcinia fruit extract and its effect on 
bread quality," Journal of Food Engineering, vol. 117, no. 4, pp. 513-520, 2013.

[57] D. S. Pillai, P. Prabhasankar, B. S. Jena, and C. Anandharamakrishnan, "Microencapsulation of Garcinia cowa fruit extract and effect of its use on pasta process and quality," International Journal of Food Properties, vol. 15, no. 3, pp. 590-604, 2012.

[58] D. Borrmann, A. P. T. R. Pierucci, S. G. F. Leite, and M. H. M. . R. Leão, "Microencapsulation of passion fruit (Passiflora) juice with n-octenylsuccinate-derivatised starch using spray-drying," Food and Bioproducts Processing, vol. 91, no. 1, pp. 2327, 2013.

[59] A. Sohail, M. S. Turner, E. K. Prabawati, A. G. A. Coombes, and B. Bhandari, "Evaluation of Lactobacillus rhamnosus GG and Lactobacillus acidophilus NCFM encapsulated using a novel impinging aerosol method in fruit food products," International Journal of Food Microbiology, vol. 157, no. 2, pp. 162166, 2012.

[60] H. Wu, N. Xue, C. L. Hou, J. T. Feng, and X. Zhang, "Microcapsule preparation of allyl isothiocyanate and its application on mature green tomato preservation," Food Chemistry, vol. 175, pp. 344-349, 2015.

[61] D. Dag, M. Kilercioglu, and M. H. Oztop, "Physical and chemical characteristics of encapsulated goldenberry (Physalis peruviana L.) juice powder," LWT - Food Science and Technology, vol. 83, pp. 86-94, 2017.

[62] M. A. Watson, J. M. Lea, and K. L. Bett-Garber, "Spray drying of pomegranate juice using maltodextrin/cyclodextrin blends as the wall material," Food Science and Nutrition, vol. 5, no. 3, pp. 820-826, 2017.

[63] R. A. Mazuco, P. M. M. Cardoso, E. S. Bindaco et al., "Maltodextrin and gum Arabic-based microencapsulation methods for anthocyanin preservation in jucara palm (Euterpe edulis Martius) fruit pulp," Plant Foods for Human Nutrition, vol. 73, no. 3, pp. 209-215, 2018.

[64] C. P. Champagne, S. Moineau, S. Lafleur, and T. Savard, "The effect of bacteriophages on the acidification of a vegetable juice medium by microencapsulated Lactobacillus plantarum," Food Microbiology, vol. 63, pp. 28-34, 2017.

[65] Y.-F. Wang, J.-X. Jia, Y.-Q. Tian et al., “Antifungal effects of clove oil microcapsule on meat products," LWT-Food Science and Technology, vol. 89, pp. 604-609, 2018.

[66] T. Huq, B. Riedl, J. Bouchard, S. Salmieri, and M. Lacroix, "Microencapsulation of nisin in alginate-cellulose nanocrystal (CNC) microbeads for prolonged efficacy against Listeria monocytogenes," Cellulose, vol. 21, no. 6, pp. 4309-4321, 2014.

[67] R. Domínguez, M. Pateiro, R. Agregán, and J. M. Lorenzo, "Effect of the partial replacement of pork backfat by microencapsulated fish oil or mixed fish and olive oil on the quality of frankfurter type sausage," Journal of Food Science and Technology, vol. 54, no. 1, pp. 26-37, 2017.

[68] R. T. Heck, R. G. Vendruscolo, M. de Araújo Etchepare et al., "Is it possible to produce a low-fat burger with a healthy $\mathrm{n}-$ $6 / \mathrm{n}-3$ PUFA ratio without affecting the technological and sensory properties?," Meat Science, vol. 130, pp. 16-25, 2017.

[69] T. Pérez-Palacios, J. Ruiz-Carrascal, E. Jiménez-Martín, J. C. Solomando, and T. Antequera, "Improving the lipid profile of ready-to-cook meat products by addition of omega-3 microcapsules: effect on oxidation and sensory analysis," Journal of the Science of Food and Agriculture, vol. 98, no. 14, pp. 5302-5312, 2018.
[70] C. Aquilani, T. Pérez-Palacios, F. Sirtori et al., "Enrichment of Cinta Senese burgers with omega-3 fatty acids. Effect of type of addition and storage conditions on quality characteristics," Grasas y Aceites, vol. 69, no. 1, p. 235, 2018.

[71] F. P. D. Castro-Cislaghi, C. D. R. E. Silva, C. B. Fritzen-Freire, J. G. Lorenz, and E. S. Sant'Anna, “_Bifidobacterium_Bb-12 microencapsulated by spray drying with whey: Survival under simulated gastrointestinal conditions, tolerance to $\mathrm{NaCl}$, and viability during storage," Journal of Food Engineering, vol. 113, no. 2, pp. 186-193, 2012.

[72] G. Shu, Y. He, L. Chen, Y. Song, J. Cao, and H. Chen, "Effect of xanthan(-)chitosan microencapsulation on the survival of Lactobacillus acidophilus in simulated gastrointestinal fluid and dairy beverage," Polymers, vol. 10, no. 6, p. 588, 2018.

[73] M. C. E. Ribeiro, K. S. Chaves, C. Gebara, F. N. S. Infante, C. R. F. Grosso, and M. L. Gigante, "Effect of microencapsulation of Lactobacillus acidophilus LA-5 on physicochemical, sensory and microbiological characteristics of stirred probiotic yoghurt," Food Research International, vol. 66, pp. 424-431, 2014.

[74] L. A. Bosnea, T. Moschakis, and C. G. Biliaderis, "Complex coacervation as a novel microencapsulation technique to improve viability of probiotics under different stresses," Food and Bioprocess Technology, vol. 7, no. 10, pp. 2767-2781, 2014.

[75] M. T. Cook, G. Tzortzis, D. Charalampopoulos, and V. V. Khutoryanskiy, "Microencapsulation of probiotics for gastrointestinal delivery," Journal of Controlled Release, vol. 162, no. 1, pp. 56-67, 2012.

[76] T. M. El-Messery, National Research Centre, Egypt, M. M. ElSaid, E. Demircan, and B. Ozçelik, "Microencapsulation of natural polyphenolic compounds extracted from apple peel and its application in yoghurt Istanbul Technical University Maslak, Turkey," Acta Scientiarum Polonorum Technologia Alimentaria, vol. 18, pp. 25-34, 2019.

[77] J. Burgain, J. Scher, S. Lebeer et al., "Significance of bacterial surface molecules interactions with milk proteins to enhance microencapsulation of Lactobacillus rhamnosus GG," Food Hydrocolloids, vol. 41, pp. 60-70, 2014.

[78] J. A. Pellicer, M. I. Fortea, J. Trabal, M. I. Rodríguez-López, J. A. Gabaldón, and E. Núñez-Delicado, "Stability of microencapsulated strawberry flavour by spray drying, freeze drying and fluid bed," Powder Technology, vol. 347, pp. 179-185, 2019.

[79] B. M. A. N. Estevinho, F. A. N. Rocha, L. M. D. S. Santos, and M. A. C. Alves, "Using water-soluble chitosan for flavour microencapsulation in food industry," Journal of Microencapsulation, vol. 30 , no. 6 , pp. 571-579, 2013.

[80] N. R. Breternitz, H. M. A. Bolini, and M. D. Hubinger, "Sensory acceptance evaluation of a new food flavoring produced by microencapsulation of a mussel (Perna perna) protein hydrolysate," LWT - Food Science and Technology, vol. 83, pp. 141-149, 2017.

[81] D. Wyspiańska, A. Z. Kucharska, A. Sokół-Łętowska, and J. Kolniak-Ostek, "Effect of microencapsulation on concentration of isoflavones during simulated in vitro digestion of isotonic drink," Food Science and Nutrition, vol. 7, no. 2, pp. 805-816, 2019.

[82] S. C. S. R. de Moura, C. L. Berling, S. P. M. Germer, I. D. Alvim, and M. D. Hubinger, "Encapsulating anthocyanins from _Hibiscus sabdariffa_L. calyces by ionic gelation: Pigment stability during storage of microparticles," Food Chemistry, vol. 241, pp. 317-327, 2018. 
[83] M. G. Santos, D. A. Carpinteiro, M. Thomazini et al., "Coencapsulation of xylitol and menthol by double emulsion followed by complex coacervation and microcapsule application in chewing gum," Food Research International, vol. 66, pp. 454-462, 2014.

[84] Meticulous Research, Top 10 companies in microencapsulation market2020, https://meticulousblog.org/top-10-companiesin-microencapsulation-market/.

[85] S. Y. Hundre, P. Karthik, and C. Anandharamakrishnan, "Effect of whey protein isolate and beta-cyclodextrin wall systems on stability of microencapsulated vanillin by spray-freeze drying method," Food Chemistry, vol. 174, pp. 16-24, 2015.

[86] A. Gharsallaoui, G. Roudaut, O. Chambin, A. Voilley, and R. Saurel, "Applications of spray-drying in microencapsulation of food ingredients: an overview," Food Research International, vol. 40, no. 9, pp. 1107-1121, 2007.

[87] A. Jamekhorshid, S. M. Sadrameli, and M. Farid, "A review of microencapsulation methods of phase change materials (PCMs) as a thermal energy storage (TES) medium," Renewable and Sustainable Energy Reviews, vol. 31, pp. 531-542, 2014.

[88] C. Jegat and J. L. Taverdet, "Stirring speed influence study on the microencapsulation process and on the drug release from microcapsules," Polymer Bulletin, vol. 44, pp. 345-351, 2000.

[89] M. C. Mauguet, J. Legrand, L. Brujes, G. Carnelle, C. Larre, and Y. Popineau, "Gliadin matrices for microencapsulation processes by simple coacervation method," Journal of Microencapsulation, vol. 19, pp. 377-384, 2008.

[90] H. Arnon-Rips and E. Poverenov, "Improving food products' quality and storability by using layer by layer edible coatings," Trends in Food Science \& Technology, vol. 75, pp. 81-92, 2018.

[91] J. Yan, Z. Luo, Z. Ban et al., "The effect of the layer-by-layer (LBL) edible coating on strawberry quality and metabolites during storage," Postharvest Biology and Technology, vol. 147, pp. 29-38, 2019.

[92] Z. H. Qi and A. Xu, "Starch-based ingredients for flavor encapsulation starch," Cereal Foods World, vol. 44, pp. 460-465, 1999.

[93] S. H. Soh and L. Y. Lee, "Microencapsulation and nanoencapsulation using supercritical fluid (SCF) techniques," Pharmaceutics, vol. 11, no. 1, p. 21, 2019.

[94] C. Y. Tai and C. S. Cheng, "Supersaturation and crystal growth in gas anti-solvent crystallization," Journal of Crystal Growth, vol. 183, no. 4, pp. 622-628, 1998.

[95] L. G. Gomez-Mascaraque, G. Sanchez, and A. Lopez-Rubio, "Impact of molecular weight on the formation of electrosprayed chitosan microcapsules as delivery vehicles for bioactive compounds," Carbohydrate Polymers, vol. 150, pp. 121130, 2016.

[96] S. Chakraborty, I. C. Liao, A. Adler, and K. W. Leong, "Electrohydrodynamics: a facile technique to fabricate drug delivery systems," Advanced Drug Delivery Reviews, vol. 61, no. 12, pp. 1043-1054, 2009.

[97] S. Neethirajan and D. S. Jayas, "Nanotechnology for the food and bioprocessing industries," Food and Bioprocess Technology, vol. 4, no. 1, pp. 39-47, 2011.

[98] L. Y. Chen, G. E. Remondetto, and M. Subirade, "Food protein-based materials as nutraceutical delivery systems," Trends in Food Science \& Technology, vol. 17, no. 5, pp. 272283, 2006. 